\title{
Pengujian Validitas dan Reliabilitas Model UTAUT 2 dan EUCS Pada Sistem Informasi Akademik
}

\author{
Shinta Aprilisa*, Samsuryadi, Sukemi \\ Fakultas Ilmu Komputer, Magister Ilmu Komputer, Universitas Sriwijaya, Palembang, Indonesia \\ Email: 1, ${ }^{*}$ shintaaprilisa97@gmail.com, ${ }^{2}$ samsuryadi@ unsri.ac.id, ${ }^{3}$ sukemi@ilkom.unsri.ac.id \\ Email Penulis Korespondensi: shintaaprilisa97@gmail.com
}

\begin{abstract}
Abstrak-Instrumen penelitian digunakan untuk mengumpulkan data atau mengukur objek dari suatu penelitian. Tujuan dari penelitian ini untuk mengetahui instrumen yang dinyatakan valid dan reliabel serta mengetahui variabel dengan nilai validitas dan reliabilitas tertinggi. Pengujian validitas dilakukan untuk mengetahui keefektifan suatu instrumen, sedangkan pengujian reliabilitas dilakukan untuk menunjukkan tingkat kehandalan dari indikator yang digunakan. Pengujian validitas dan reliabilitas menggunakan software SmartPLS versi 3.3.2 dengan skala pengukuran yaitu skala likert. Pengujian validitas dilakukan dengan melihat nilai average variance extracted (AVE) dan perbandingan nilai latent variable correlations, sedangkan pada pengujian reliabilitas dengan melihat nilai composite reliability. Populasi pada penelitian ini adalah mahasiswa aktif di Universitas Islam Negeri (UIN) Raden Fatah Palembang yang berjumlah 19.260 mahasiswa dengan penentuan sampel menggunakan rumus slovin dengan tingkat signifikansi (level of significance) $=5 \%$. Pengumpulan data pada penelitian ini dilakukan dengan penyebaran kuesioner secara online. Kuesioner dibuat berdasarkan indikator pada model yang digunakan, dimana model yang digunakan yaitu UTAUT 2 dan EUCS. Model UTAUT 2 dapat digunakan untuk mengukur tingkat penerimaan pengguna terhadap sistem yang terdiri dari variabel performance expectancy, effort expectancy, social influence, facilitating condition, hedonic motivation, perceived value, habit, dan behavioral intention. Selanjutnya, model EUCS adalah digunakan untuk mengukur tingkat kepuasan pengguna yang terdiri dari variabel content, accuracy, format, ease of use, timeliness, dan user satisfaction. Hasil dari pengujian validitas dan reliabilitas menyatakan bahwa semua indikator dinyatakan valid dan reliabel dengan nilai AVE $>0.50$ pada pengujian validitas dan nilai composite reliability $>0.70$ pada pengujian reliabilitas. Pengujian validitas dengan nilai tertinggi terdapat pada variabel ease of use dengan nilai AVE yaitu 0.826 dan pengujian reliabilitas dengan nilai tertinggi terdapat pada variabel performance expectancy dengan nilai composite reliability yaitu 0.924. Dengan penelitian ini diharapkan dapat memperoleh variabel pada model untuk mengevaluasi penerimaan dan kepuasan pengguna terhadap sistem informasi akademik.
\end{abstract}

Kata Kunci: Validitas; Reliabilitas; SmartPLS; UTAUT 2; EUCS; Sistem Informasi Akademik

Abstract-The research instrument is used to collect data or measure the object of a study. The purpose of this study was to determine which instruments were declared valid and reliable and to find out the variables with the highest validity and reliability values. Validity testing is carried out to determine the effectiveness of an instrument, while reliability testing is carried out to show the level of reliability of the indicators used. Testing the validity and reliability using software SmartPLS version 3.3.2 with a measurement scale that is Likert scale. Validity testing is done by looking at the average variance extracted (AVE) value and the comparison of the latent variable correlations values, while reliability testing is done by looking at the composite reliability value. The population in this study were active students at the State Islamic University (UIN) Raden Fatah Palembang, totaling 19,260 students with the determination of the sample using the Slovin formula with a level of significance $=5 \%$. Data collection in this study was carried out by distributing online questionnaires. The questionnaire was made based on indicators on the model used, where the models used were UTAUT 2 and EUCS. The UTAUT 2 model can be used to measure the level of user acceptance of the system consisting of the variables of performance expectancy, effort expectancy, social influence, facilitating conditions, hedonic motivation, perceived value, habit, and behavioral intention. Furthermore, the EUCS model is used to measure the level of user satisfaction which consists of content, accuracy, format, ease of use, timeliness, and user satisfaction variables. The results of the validity and reliability testing state that all indicators are valid and reliable with an AVE value $>0.50$ in the validity test and the composite reliability value $>0.70$ in the reliability test. The validity test with the highest value is found in the ease of use variable with an AVE value of 0.826 and reliability testing with the highest value is found in the performance expectancy variable with a composite reliability value of 0.924 . With this research, it is expected to obtain variables in the model to evaluate user acceptance and satisfaction with academic information systems.

Keywords: Validity; Reliability; SmartPLS; UTAUT 2; EUCS; Academic Information System

\section{PENDAHULUAN}

Teknologi dan informasi telah menjadi fasilitas utama dalam berbagai kegiatan dalam aktivitas pendidikan, perkantoran, komersial dan industri. Pada dunia pendidikan, salah satu yang menggunakan fasilitas ini adalah pada bidang pelayanan administrasi akademik di perguruan tinggi [1]. Pada UIN Raden Fatah Palembang dalam pelayanan terhadap mahasiswa berusaha memberikan pelayanan yang terbaik. Hal ini dibuktikan dengan pemanfaatan teknologi informasi untuk sistem informasi akademik, layanan akademik dengan memanfaatkan teknologi ini dapat dikatakan sangat tepat agar dapat memudahkan pada pengurusan data akademik mahasiswa agar lebih cepat dan efisien [2]. Sistem informasi akademik adalah suatu sistem yang menyediakan layanan akademik di suatu lembaga pendidikan, dan membantu dalam mengelola operasional akademik termasuk kegiatan yang menyangkut akademik mahasiswa. Sistem informasi akademik menjadi salah satu bentuk penting dalam sebuah lembaga akademik karena fasilitas ini dapat mengelola proses bisnis yang sangat besar di sebuah perguruan tinggi [3]. Sistem informasi akademik di UIN Raden Fatah Palembang dikelola oleh pihak PUSTIPD (Pusat Teknologi Informasi dan Pangakalan Data) UIN Raden Fatah Palembang. sistem informasi akademik dalam 
kegiatan perkuliahan mampu menumbuhkan citra yang baik bagi perguruan tinggi agar dapat meningkatkan kepercayaan mahasiswa [4].

Evaluasi sistem informasi akademik dapat diukur dengan mengevaluasi tingkat penerimaan dan kepuasan sistem tersebut. Terdapat beberapa model yang dapat digunakan dalam mengevaluasi sistem informasi akademik, untuk mengevaluasi tingkat penerimaan pengguna dapat menggunakan model UTAUT 2. Model UTAUT 2 (unified theory of acceptance and use of technology) merupakan model pengujian sistem informasi dengan persepsi pengguna terhadap penerimaan teknologi yang berpengaruh terhadap perilaku pengguna sistem informasi [5]. Pada model UTAUT 2 terdapat variabel yang akan digunakan pada penelitian ini yaitu variabel performance expectancy, effort expectancy, social influence, facilitating conditions, hedonic motivation, perceived value dan habit [6]. Tujuan dari model UTAUT 2 yaitu untuk mengevaluasi penerimaan dan penggunaan teknologi dalam segi pengguna [7]. Selanjutnya untuk mengevaluasi kepuasan pengguna dapat menggunakan model EUCS. Model EUCS (end user computing satisfaction) merupakan model yang dapat digunakan untuk mengukur kepuasan pengguna akhir menurut pengalaman dalam menggunakan sistem tersebut [8]. Pada model EUCS terdapat 5 variabel yang dapat digunakan untuk mengukur kepuasan yaitu variabel content, accuracy, format, ease of use, dan timeliness [9].

Pada penelitian terdahulu menyatakan bahwa sebelum melakukan penyebaran kuesioner kepada seluruh responden perlu dilakukan uji validitas dan reliabilitas terhadap variabel dan instrumen yang digunakan [10]. Hal ini diharapkan untuk membuktikan baik atau tidaknya suatu instrumen penelitian dengan mengukur ketepatan dan keandalan dari instrumen dan variabel yang digunakan [11]. Mengukur validitas dan reliabilitas dapat menggunakan bantuan software yang ada, pada penelitian ini data akan diolah menggunakan software SmartPLS versi 3.3.2. Pada pengujian validitas dilakukan dengan mengukur validitas konvergen dengan melihat nilai average variance extracted (AVE) dan validitas diskriminan dengan melihat nilai kuadrat AVE dan nilai latent variable correlations, sedangkan pada pengujian reliabilitas menggunakan nilai composite reliability [9]. Setelah variabel dan indikator penelitian dinyatakan valid dan reliabel, maka indikator tersebut dapat digunakan untuk penelitian dalam mengevaluasi sistem informasi akademik dilihat dari sisi pengguna akhir, yaitu tingkat penerimaan dan kepuasan pengguna sistem informasi akademik [12].

Batasan masalah pada penelitian ini yaitu penelitian ini dilakukan pada UIN Raden Fatah Palembang dengan objek yang akan dievaluasi adalah sistem informasi akademik. Pada penelitian ini responden yang akan digunakan adalah mahasiswa aktif yang berjumlah 19.260 mahasiswa. Penentuan sampel yang digunakan dengan teknik simple random sampling yaitu tanpa memperhatikan strata yang ada pada populasi tersebut [13]. Penentuan jumlah sampel menggunakan rumus slovin dengan taraf signifikansi 5\%, jumlah sampel inilah yang akan digunakan sebagai responden dalam penyebaran kuesioner.

\section{METODOLOGI PENELITIAN}

Penelitian ini menggunakan metode kuantitatif dengan metode penelitian deskriptif untuk menggambarkan hasil penelitian yang dilakukan. Penelitian kuantitatif digunakan pada penelitian yang menggunakan data berupa angkaangka dan analisis dengan statistik [14].

\subsection{Tahapan Penelitian}

Tahapan penelitian merupakan langkah-langkah yang menjadi acuan yang akan dilakukan pada penelitian. Tahapan yang dilakukan pada penelitian ini seperti pada gambar 2 berikut:

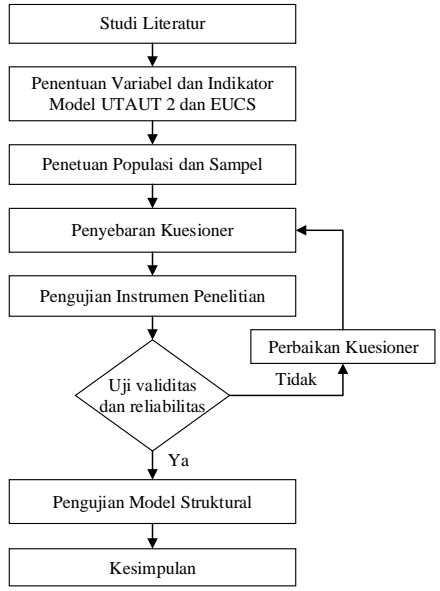

Gambar 1. Tahapan Penelitian Pada Pengujian Validitas dan Reliabilitas

a. Studi Literatur 
Studi literatur untuk mengkaji dan mengetahui secara teoritis metode yang digunakan dalam pemecahan masalah yaitu menggunakan model UTAUT 2 dan EUCS serta bagaimana proses yang berjalan pada sistem informasi akademik.

b. Penentuan Variabel dan Indikator Model UTAUT 2 dan EUCS

Tahapan selanjutnya adalah penentuan variabel dan membuat indikator dari model yang digunakan yaitu model UTAUT 2 dan EUCS. Berikut ini Tabel 1 variabel dan indikator yang digunakan.

Tabel 1. Variabel dan Indikator

\begin{tabular}{|c|c|c|}
\hline Variabel & & Indikator \\
\hline \multirow{5}{*}{$\begin{array}{c}\text { Performance } \\
\text { Expectancy } \\
\text { (PE) }\end{array}$} & PE1 & Kemudahan mendapatkan informasi \\
\hline & PE2 & Meningkatkan peluang \\
\hline & PE3 & Meningkatkan produktivitas \\
\hline & PE4 & Meningkatkan efektivitas \\
\hline & EE1 & Kemudahan penggunaan \\
\hline \multirow{3}{*}{$\begin{array}{l}\text { Effort Expectancy } \\
\text { (EE) }\end{array}$} & EE2 & Kemudahan untuk dipelajari \\
\hline & EE3 & Kemudahan interaksi \\
\hline & EE4 & Kemudahan menjadi ahli \\
\hline \multirow{3}{*}{$\begin{array}{l}\text { Social Influence } \\
\text { (SI) }\end{array}$} & SI1 & Faktor dukungan dari kemajuan teknologi \\
\hline & $\mathrm{SI} 2$ & Faktor lingkungan \\
\hline & SI3 & Dukungan dari orang berpengaruh \\
\hline Facilitating & $\mathrm{FC} 1$ & Kondisi internet yang memfasilitasi \\
\hline \multirow{2}{*}{$\begin{array}{c}\text { Condition } \\
\text { (FC) }\end{array}$} & $\mathrm{FC} 2$ & Pengetahuan dalam pengoperasian \\
\hline & FC3 & Bantuan dalam pengoperasian \\
\hline Hedonic & HM1 & Menyenangkan \\
\hline \multirow{2}{*}{$\begin{array}{c}\text { Motivation } \\
\text { (HM) }\end{array}$} & HM2 & User friendly \\
\hline & HM3 & Menarik \\
\hline \multirow{3}{*}{$\begin{array}{c}\text { Perceived Value } \\
\text { (PV) }\end{array}$} & PV1 & Sistem bermanfaat \\
\hline & PV2 & Sistem menunjang kegiatan \\
\hline & PV3 & Sistem memiliki nilai yang baik \\
\hline & $\mathrm{H} 1$ & Rutinitas atau kebiasaan \\
\hline \multirow[t]{2}{*}{ Habit $(\mathrm{H})$} & $\mathrm{H} 2$ & Kebutuhan atau keharuan \\
\hline & H3 & Keharusan \\
\hline \multirow{3}{*}{$\begin{array}{l}\text { Behavioral } \\
\text { Intention (BI) }\end{array}$} & BI1 & Menggunakan lebih sering untuk mempercepat kegiatan \\
\hline & $\mathrm{BI} 2$ & Selalu menggunakan simak \\
\hline & $\mathrm{BI} 3$ & Menggunakan sistem secara teratur \\
\hline \multirow{4}{*}{ Content (C) } & $\mathrm{C} 1$ & Isi yang dihasilkan sangat membantu pengguna \\
\hline & $\mathrm{C} 2$ & Menyediakan informasi yang jelas \\
\hline & $\mathrm{C} 3$ & Menyediakan informasi secara tepat \\
\hline & $\mathrm{C} 4$ & Semua informasi tentang yang dibutuhkan tersedia \\
\hline \multirow{2}{*}{ Accuracy (A) } & A1 & Menampilkan informasi yang benar dan akurat \\
\hline & A2 & Pengguna merasa puas terhadap keakuratan sistem \\
\hline \multirow{2}{*}{ Format $(\mathrm{F})$} & $\mathrm{F} 1$ & Menyajikan output dalam tampilan yang bermanfaat \\
\hline & $\mathrm{F} 2$ & Tampilan interface memberikan informasi yang jelas \\
\hline \multirow{2}{*}{ Timeliness $(\mathrm{T})$} & $\mathrm{T} 1$ & Informasi yang dibutuhkan dapat diperoleh dengan cepat \\
\hline & $\mathrm{T} 2$ & Menampilkan informasi yang terbaru \\
\hline \multirow{2}{*}{ Ease of Use (E) } & E1 & Sangat mudah digunakan \\
\hline & $\mathrm{E} 2$ & Kemudahan akses dari mana saja dan kapan saja \\
\hline \multirow{5}{*}{$\begin{array}{c}\text { User Satisfaction } \\
\text { (US) }\end{array}$} & US1 & Konten atau isi yang disediakan sesuai pengguna \\
\hline & US2 & Memberikan layanan secara akurat yang pengguna butuhkan \\
\hline & US3 & Tampilan interface dengan struktur yang teratur memberikan kepuasan \\
\hline & US4 & Kemudahan penggunaan dalam memberikan kepuasan pengguna \\
\hline & US5 & Ketepatan waktu dari penggunaan secara cepat \\
\hline
\end{tabular}

c. Penentuan Populasi dan Sampel

Populasi penelitian ini adalah semua mahasiswa aktif di UIN Raden Fatah Palembang terdiri dari 9 fakultas yang berjumlah 19.260 mahasiswa. Sedangkan sampel yang akan digunakan terdiri dari populasi pengguna Sistem Informasi Akademik dengan teknik pengambilan sampel yaitu simple random sampling. Teknik pengambilan sampel yang dilakukan secara acak tanpa memperhatikan strata yang ada pada populasi [15]. Penentuan sampel digunakan dengan taraf signifikansi e $=5 \%$ dengan menggunakan rumus slovin seperti pada persamaan 1 berikut. 


$$
\mathrm{n}=\frac{\mathrm{N}}{1+\mathrm{N} \cdot \mathrm{e}^{2}}
$$

Berdasarkan rumus slovin, maka diperoleh jumlah sampel penelitian sebagai berikut:

$$
\begin{aligned}
& \mathrm{n}=\frac{19260}{1+19260 \times 0.05^{2}} \\
& \mathrm{n}=\frac{19260}{1+48.15} \\
& \mathrm{n}=391.86 \\
& \mathrm{n}=392
\end{aligned}
$$

d. Penyebaran Kuesioner

Tahapan ini melakukan penyebaran kuesioner kepada 392 mahasiswa di UIN Raden Fatah Palembang tanpa memperhatikan strata yang ada seperti jenis kelamin, usia, angkatan, dan fakultas. Penyebaran kuesioner ini dilakukan secara online dengan bantuan google form. Skala pengukuran pada penelitian ini menggunakan skala likert yaitu skala pengukuran untuk mengukur sikap atau pendapat seseorang tentang suatu kejadian dengan skor 5 poin [16]. Bentuk jawaban pada skala ini menggunakan alternatif jawaban seperti pada Tabel 2:

Tabel 2. Skor Jawaban Responden

\begin{tabular}{cc}
\hline Jawaban & Skor \\
\hline Sangat Setuju (SS) & 5 \\
Setuju (S) & 4 \\
Kurang Setuju (KS) & 3 \\
Tidak Setuju (TS) & 2 \\
Sangat Tidak Setuju (STS) & 1 \\
\hline
\end{tabular}

e. Pengujian Instrumen Penelitian

Pada tahapan ini dilakukan pengujian validitas dan reliabilitas terhadap instrumen variabel untuk menentukan ketepatan instrumen penelitian dan mengukur keandalan dari variabel yang digunakan. Pengujian ini dilakukan dengan menggunakan software SmartPLS versi 3.3.2.

f. Uji Validitas dan Reliabilitas

Pengujian validitas dan reliabilitas dilakukan dengan hasil jika pengujian menunjukkan bahwa instrumen dinyatakan valid dan reliabel maka data dapat digunakan untuk tahapan selanjutnya. Tetapi jika instrumen tidak valid dan reliabel, maka dilakukan perbaikan kuesioner dan dilakukan penyebaran kuesioner ulang. Pada pengujian validitas terdiri dari 2 tahapan yaitu pengujian validitas konvergen dan pengujian validitas diskriminan [17]. Pengujian validitas konvergen diukur dengan melihat nilai average variance extracted $(\mathrm{AVE})>0.5$ [9]. Nilai AVE diukur melalui persamaan berikut [18]:

$A V E=\frac{\sum_{i=1}^{n} \widehat{\lambda}_{i}^{2}}{\sum_{i=1}^{n} \widehat{\lambda}_{i}^{2}+\sum_{i=1}^{n} \operatorname{var}\left(\hat{\varepsilon}_{i}\right)}$

Sedangkan untuk pengujian validitas diskriminan diukur dengan melihat perbandingan nilai kuadrat AVE harus lebih besar daripada nilai latent variable correlation. Setelah variabel dinyatakan valid, selanjutnya dilakukan pengujian reliabilitas. Pengujian reliabilitas dapat dilakukan dengan melihat nilai Cronbach alpha atau nilai composite reliability. Menguji reliabilitas dengan melihat nilai Cronbach alpha akan memberikan nilai lebih rendah (under estimate) sehingga lebih disarankan menggunakan composite reliability [17]. Variabel dinyatakan reliabel dengan ketentuan jika nilai composite reliability > 0.7 [9]. Nilai composite reliability diukur menggunakan persamaan berikut [18]:

$\hat{\rho}=\frac{\left(\sum_{i=1}^{n} \hat{\lambda}_{i}^{2}\right)^{2}}{\left(\sum_{i=1}^{n} \hat{\lambda}_{i}^{2}\right)^{2}+\sum_{i=1}^{n} \operatorname{var}\left(\hat{\varepsilon}_{i}\right)}$

g. Pengujian Model Struktural

Evaluasi model struktural dengan melihat nilai $R$-square dan $Q$-square. Nilai $R$-square digunakan untuk mengukur tingkat variasi antara variabel independen terhadap variabel dependen. Penentuan nilai $R$-square dengan nilai yang mendekati angka 1 dinyatakan dengan semakin tinggi nilai $R$-square maka model yang digunakan semakin baik [18]. Menghitung nilai $R$-square dengan persamaan berikut.

$$
R^{2}=\sum_{h=1}^{H} \beta_{j h} \operatorname{cor}\left(X_{j h}, Y_{j}\right)
$$

Selanjutnya setelah mendapatkan $R$-square akan dilakukan pengujian $Q$-square untuk melihat predictive relevancy yaitu mengukur seberapa baik nilai observasi yang dihasilkan dari model yang digunakan. Penetuan nilai $Q$-square yaitu jika nilai $Q$-square $>0$ menunjukkan model mempunyai predictive relevance sedangkan 
jika nilai $Q$-square $<0$ menunjukkan model kurang memiliki predictive relevance Menghitung nilai $Q$-square menggunakan persamaan berikut.

$$
Q^{2}=1-\left(1-R_{1}^{2}\right)\left(1-R_{2}^{2}\right) \ldots\left(1-R_{p}^{2}\right)
$$

h. Kesimpulan

Membuat kesimpulan dari penelitian yang dilakukan untuk menjawab permasalahan yang diajukan yaitu menentukan apakah variabel dan indikator pada kuesioner yang diajukan valid dan reliabel.

\subsection{Model UTAUT 2 dan EUCS}

Pada penelitian ini model yang digunakan adalah model UTAUT 2 dan EUCS. Model UTAUT 2 (Unified Theory of Acceptance and Use of Technology 2) merupakan model yang dikembangkan oleh Venkatesh dkk tahun 2012, dimana model ini digunakan untuk menguji sistem informasi dengan persepsi pengguna terhadap penerimaan teknologi dan mengidentifikasi faktor yang berpengaruh terhadap perilaku pengguna berbasis teori [5]. Model UTAUT 2 merupakan model pengembangan dari model UTAUT, dimana pada UTAUT 2 dilakukan penambahan tiga variabel utama yaitu Motivasi Ketertarikan (Hedonic Motivation), Nilai Harga (Price Value), dan Kebiasaan (Habit), sedangkan variabel pendukung Voluntariness of Use dihilangkan [19]. Perbandingan antara UTAUT dan UTAUT 2 menunjukkan hasil dari penambahan tiga variabel yaitu peningkatan pada variabel Behavioral Intention (56 persen menjadi 74 persen) dan Technology Use (40 persen menjadi 52 persen) [6]. Pada penelitian [7] menyatakan bahwa dari pengembangan yang dilakukan, maka variabel yang terdapat pada model UTAUT 2 yaitu performance expectancy, effort expectancy, social influence, facilitating conditions, hedonic motivation, price value dan habit. Dalam UTAUT 2 hanya terdapat 3 variabel moderator yaitu age, gender, dan experience. Pada penelitian ini yang akan dijadikan objek adalah sistem informasi akademik, sistem ini tidak berfokus pada biaya yang dikeluarkan terhadap teknologi atau sistem yang digunakan tetapi dapat melihat nilai yang diberikan dan diterima pengguna dari suatu sistem. Dikarenakan alasan tersebut maka pada penelitian ini variabel price value akan diganti dengan variabel perceived value [6], [20].

Model EUCS (End-User Computing Satisfaction) yang dikembangkan oleh Doll dan Torkzadeh tahun 1998. Model ini merupakan metode untuk mengukur tingkat kepuasan pengguna terhadap sistem informasi [21]. Evaluasi yang digunakan dalam model EUCS lebih menekankan kepada kepuasan pengguna akhir menurut pengalaman dalam menggunakan sistem tersebut [9]. Pada model EUCS terdapat lima variabel yang digunakan untuk mengukur kepuasan pengguna terdiri dari isi (content) sistem aplikasi, keakuratan (accuracy) data yang ditampilkan, format (format) dari sisi tampilan antarmuka sistem, kemudahan dalam menggunakan (ease of use), dan ketepatan waktu (timeliness) dalam menampilkan informasi yang dibutuhkan [8], [21]. Berikut ini Gambar 1 model yang digunakan pada penelitian ini berdasarkan jurnal terdahulu.

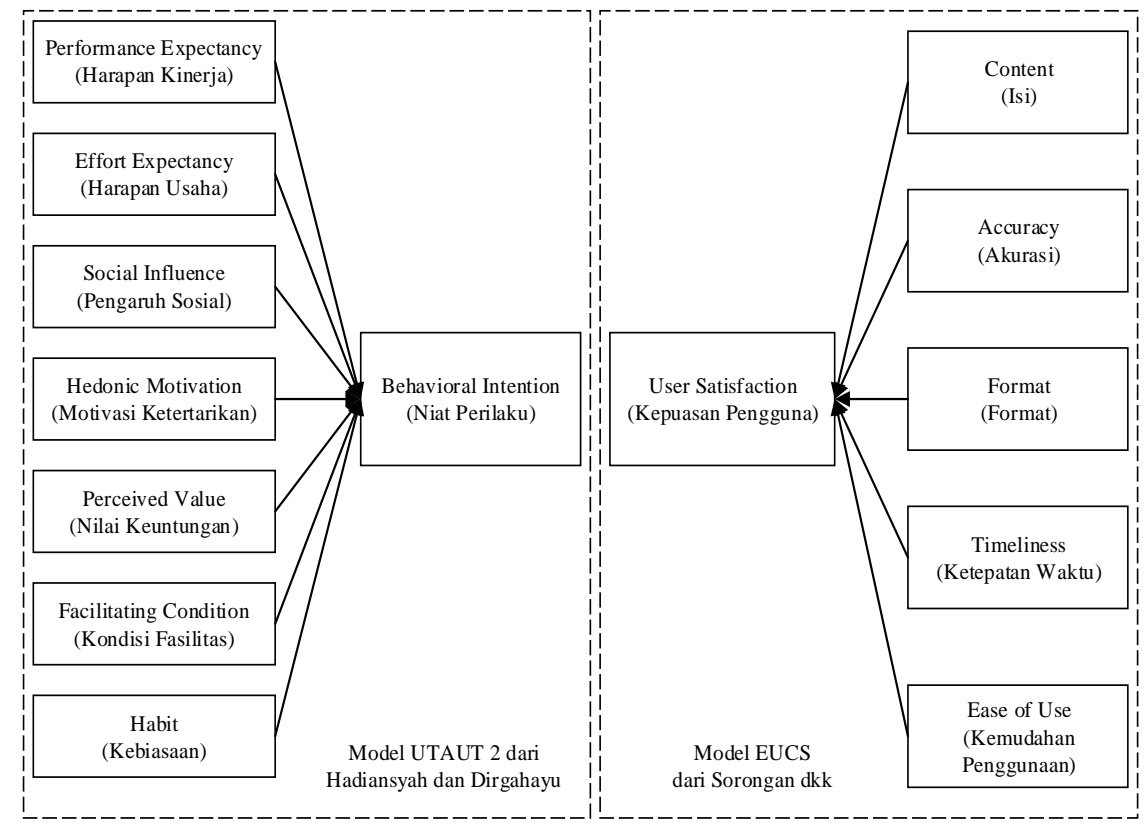

Gambar 2. Model UTAUT 2 dan EUCS

\section{HASIL DAN PEMBAHASAN}

Penguji validitas dan reliabilitas instrumen penelitian dengan menggunakan data kuesioner yang telah disebarkan kepada sampel penelitian berjumlah 392 mahasiswa di UIN Raden Fatah Palembang. Penyebaran kuesioner ini 
ISSN 2614-5278 (media cetak), ISSN 2548-8368 (media online)

Available Online at https://ejurnal.stmik-budidarma.ac.id/index.php/mib DOI 10.30865/mib.v5i3.3074

dengan teknik simple random sampling atau tanpa memperhatikan strata yang ada pada populasi tersebut. Berikut ini langkah-langkah pada pengujian validitas dan reliabilitas :

\subsection{Uji Validitas Konvergen}

Pengujian validitas konvergen bertujuan untuk menunjukkan ukuran sejauh mana sebuah indikator berkolerasi terhadap indikator lain terhadap indikator konstruk yang sama. Uji validitas dilakukan untuk mengukur tingkat validitas suatu instrument dimana indikator dapat dinyatakan valid jika nilai AVE (>0.5) [9].

Tabel 3. Hasil Uji Nilai AVE

\begin{tabular}{lc}
\hline \multicolumn{1}{c}{ Variabel } & AVE \\
\hline Behavioral Intention (BI) & 0.740 \\
Effort Expectancy (EE) & 0.731 \\
Facilitating Condition (FC) & 0.725 \\
Habit $(\mathrm{H})$ & 0.747 \\
Hedonic Motivation (HM) & 0.749 \\
Perceived Value (PV) & 0.754 \\
Performance Expectancy (PE) & 0.738 \\
Social Influence (SI) & 0.763 \\
Accuracy (A) & 0.791 \\
Content (C) & 0.691 \\
Ease of Use (E) & 0.826 \\
Format (F) & 0.811 \\
Timeliness (T) & 0.801 \\
User Satisfaction (US) & 0.676 \\
\hline
\end{tabular}

Berdasarkan tabel 3 nilai AVE untuk masing-masing variabel adalah behavioral intention $=0.740$, effort expectancy $=0.731$, facilitating condition $=0.725$, habit $=0.747$, hedonic motivation $=0.749$, perceived value $=$ 0.754 , performance expectancy $=0.738$, social influence $=0.763$, accuracy $=0.791$, content $=0.691$, ease of use $=0.826$, format $=0.811$, timeliness $=0.801$, dan user satisfaction $=0.676$. Maka dapat disimpulkan bahwa nilai AVE diatas 0.5 yang artinya semua variabel dinyatakan valid sehingga pengujian dapat dilanjutkan ke tahap selanjutnya yaitu uji validitas diskriminan.

\subsection{Uji Validitas Diskriminan}

Uji validitas diskriminan dilakukan dengan membandingkan nilai kuadrat AVE dengan nilai latent variable correlations. Berikut Tabel 4 dan 5 perbandingan nilai kuadrat AVE dan korelasi antar variabel pada model UTAUT 2 dan model EUCS.

Tabel 4. Nilai Latent Variable Correlations, AVE, dan Akar Kuadrat AVE model UTAUT 2

\begin{tabular}{ccccccccccc}
\hline & BI & EE & FC & H & HM & PV & PE & SI & AVE & Kuadrat AVE \\
\hline BI & 1.000 & 0.784 & 0.792 & 0.820 & 0.820 & 0.797 & 0.770 & 0.777 & 0.740 & 0.860 \\
EE & 0.784 & 1.000 & 0.826 & 0.791 & 0.814 & 0.766 & 0.842 & 0.841 & 0.731 & 0.855 \\
FC & 0.792 & 0.826 & 1.000 & 0.809 & 0.838 & 0.791 & 0.777 & 0.800 & 0.725 & 0.851 \\
H & 0.820 & 0.791 & 0.809 & 1.000 & 0.814 & 0.787 & 0.747 & 0.815 & 0.747 & 0.864 \\
HM & 0.820 & 0.814 & 0.838 & 0.814 & 1.000 & 0.809 & 0.778 & 0.804 & 0.749 & 0.865 \\
PV & 0.797 & 0.766 & 0.791 & 0.787 & 0.809 & 1.000 & 0.790 & 0.749 & 0.754 & 0.868 \\
PE & 0.770 & 0.842 & 0.777 & 0.747 & 0.778 & 0.790 & 1.000 & 0.758 & 0.738 & 0.859 \\
SI & 0.777 & 0.841 & 0.800 & 0.815 & 0.804 & 0.749 & 0.758 & 1.000 & 0.763 & 0.873 \\
\hline
\end{tabular}

Berdasarkan Tabel 4 menunjukkan bahwa pada variabel behavioral intention, effort expectancy, facilitating condition, habit, hedonic motivation, perceived value, performance expectancy, dan social influence untuk nilai akar kuadrat AVE lebih besar daripada nilai korelasi antar variabel laten pada masing-masing variabel laten. Hasil ini menunjukkan bahwa pada model UTAUT 2 dari 8 variabel yang digunakan semuanya dinyatakan valid. Selanjutnya Tabel 5 nilai latent variable correlations dan akar kuadrat AVE pada model EUCS.

Tabel 5. Nilai Latent Variable Correlations, AVE, dan Akar Kuadrat AVE model EUCS

\begin{tabular}{ccccccccc}
\hline & $\mathrm{A}$ & $\mathrm{C}$ & $\mathrm{E}$ & $\mathrm{F}$ & $\mathrm{T}$ & $\mathrm{US}$ & AVE & Kuadrat AVE \\
\hline $\mathrm{A}$ & 1.000 & 0.834 & 0.741 & 0.771 & 0.754 & 0.813 & 0.791 & 0.889 \\
$\mathrm{C}$ & 0.834 & 1.000 & 0.759 & 0.776 & 0.761 & 0.844 & 0.691 & 0.831 \\
$\mathrm{E}$ & 0.741 & 0.759 & 1.000 & 0.771 & 0.763 & 0.814 & 0.826 & 0.909 \\
$\mathrm{~F}$ & 0.771 & 0.776 & 0.771 & 1.000 & 0.769 & 0.820 & 0.811 & 0.901 \\
$\mathrm{~T}$ & 0.754 & 0.761 & 0.763 & 0.769 & 1.000 & 0.804 & 0.801 & 0.895 \\
$\mathrm{US}$ & 0.813 & 0.844 & 0.814 & 0.820 & 0.804 & 1.000 & 0.676 & 0.822 \\
\hline
\end{tabular}


ISSN 2614-5278 (media cetak), ISSN 2548-8368 (media online)

Available Online at https://ejurnal.stmik-budidarma.ac.id/index.php/mib DOI 10.30865/mib.v5i3.3074

Berdasarkan Tabel 5 menunjukkan bahwa pada variabel accuracy, content, ease of use, format, timeliness, dan user satisfaction untuk nilai akar kuadrat AVE lebih besar daripada nilai korelasi antar variabel laten pada masingmasing variabel laten yang artinya dari 6 variabel yang digunakan pada model EUCS dinyatakan valid.

\subsection{Uji Reliabilitas}

Uji reliabilitas dilakukan dengan melihat nilai composite reliability jika nilai composite reliability (>0.7) maka menunjukkan nilai yang memuaskan [9]. Berikut Tabel 6 hasil uji reliabilitas dengan SmartPLS.

Tabel 6. Hasil Uji Reliabilitas

\begin{tabular}{lc}
\hline \multicolumn{1}{c}{ Variabel } & Composite Reliability \\
\hline Behavioral Intention (BI) & 0.895 \\
Effort Expectancy (EE) & 0.916 \\
Facilitating Condition (FC) & 0.888 \\
Habit $(\mathrm{H})$ & 0.898 \\
Hedonic Motivation (HM) & 0.899 \\
Perceived Value (PV) & 0.894 \\
Performance Expectancy (PE) & 0.924 \\
Social Influence (SI) & 0.906 \\
Accuracy (A) & 0.884 \\
Content $(\mathrm{C})$ & 0.899 \\
Ease of Use (E) & 0.890 \\
Format $(\mathrm{F})$ & 0.895 \\
Timeliness $(\mathrm{T})$ & 0.905 \\
User Satisfaction (US) & 0.912 \\
\hline
\end{tabular}

Berdasarkan Tabel 6 nilai composite reliability pada masig-masing variabel adalah behavioral intention = 0.895 , effort expectancy $=0.916$, facilitating condition $=0.888$, habit $=0.898$, hedonic motivation $=0.899$, perceived value $=0.894$, performance expectancy $=0.924$, social influence $=0.906$, accuracy $=0.884$, content $=$ 0.899 , ease of use $=0.890$, format $=0.895$, timeliness $=0.905$, dan user satisfaction $=0.912$. Sehingga dapat disimpulkan bahwa semua nilai composite reliability lebih besar dari 0.7 menunjukkan bahwa indikator yang diajukan peneliti mempunyai nilai statistik yang baik atau terkategori reliabel, sehingga variabel dan indikator yang diajukan pada penelitian ini dapat digunakan untuk mengevaluasi sistem informasi akademik dengan mengukur tingkat penerimaan dan kepuasan pengguna.

\subsection{Pengujian Model Struktural}

Pengujian model struktural untuk mendapatkan nilai $R$-square dengan perhitungan menggunakan SmartPLS. Nilai $R$-square seperti ditunjukkan pada tabel 7 berikut.

Tabel 7. Nilai $R$-square

\begin{tabular}{lc}
\hline \multicolumn{1}{c}{ Variabel } & Nilai $R$-square \\
\hline Behavioral Intention (BI) & 0.773 \\
User Satisfaction $(U S)$ & 0.824 \\
\hline
\end{tabular}

Berdasarkan tabel 7 menunjukkan bahwa nilai $R$-square untuk variabel behavioral intention sebesar 0.773 yang berarti persentase besarnya pengaruh performance expectancy, effort expectancy, social influence, hedonic motivation, perceived value, facilitating condition, dan habit terhadap behavioral intention adalah sebesar $77.3 \%$ sedangkan $22.7 \%$ dipengaruhi oleh faktor lain. Sedangkan nilai $R$-square untuk variabel user satisfaction sebesar 0.824 yang berarti persentase besarnya pengaruh content, accuracy, format, timeliness, dan ease of use terhadap user satisfaction adalah sebesar $82.4 \%$ sedangkan sisanya yaitu $17.6 \%$ dipengaruhi oleh faktor lainnya. Selanjutnya penilaian goodness of fit yang bisa ditentukan dengan melihat nilai $Q$-square. Nilai $Q$-square dinyatakan semakin fit atau baik dengan data jika nilai $R$-square semakin tinggi. Berikut perhitungan $Q$-square:

$$
\begin{aligned}
Q^{2} & =1-\left(1-R_{1}^{2}\right)\left(1-R_{2}^{2}\right) \ldots\left(1-R_{p}^{2}\right) \\
Q^{2} & \\
& =1-(1-0.773) \times(1-0.824) \\
& =1-(0.227) \times(0.176) \\
& =1-0.04 \\
& =0.96
\end{aligned}
$$

Dari hasil perhitungan diketahui nilai $Q$-square sebesar 0.96 yang berarti besar keberagaman dari data penelitian dapat dijelaskan oleh model struktural yang dikembangkan pada penelitian ini sebesar $96 \%$. Berdasarkan hasil $Q$-square, maka dinyatakan bahwa model struktural pada penelitian ini telah memiliki goodness of fit yang baik. 
ISSN 2614-5278 (media cetak), ISSN 2548-8368 (media online)

Available Online at https://ejurnal.stmik-budidarma.ac.id/index.php/mib DOI 10.30865/mib.v5i3.3074

\section{KESIMPULAN}

Berdasarkan pengolahan data yang telah dilakukan dapat disimpulkan bahwa semua indikator pada model UTAUT 2 dan EUCS dinyatakan valid dan reliabel. Pengujian ini menggunakan data kuesioner sebanyak 392 responden. Pada pengujian validitas dan reliabilitas terdapat variabel atau indikator dengan nilai tertinggi dan terendah. Pada pengujian validitas, variabel dengan nilai tertinggi terdapat pada variabel ease of use dengan nilai AVE yaitu 0.826 dan variabel dengan nilai terendah terdapat pada variabel user satisfaction dengan nilai AVE yaitu 0.676. Sedangkan pada pengujian reliabilitas diketahui nilai tertinggi terdapat pada variabel performance expectancy dengan nilai composite reliability yaitu 0.924 dan nilai terendah pada variabel accuracy dengan nilai composite reliability yaitu 0.884 . Berdasarkan hasil tersebut dapat ditarik kesimpulan bahwa pada pengujian validitas dan reliabilitas, pengujian dengan nilai tertinggi dan terendah terdapat pada variabel yang berbeda. Selanjutnya dari pengujian $R$-square menyatakan bahwa besarnya pengaruh performance expectancy, effort expectancy, social influence, hedonic motivation, perceived value, facilitating condition, dan habit terhadap behavioral intention sebesar 77.3\% sedangkan besarnya pengaruh content, accuracy, format, timeliness, dan ease of use terhadap user satisfaction sebesar $82.4 \%$. Nilai $R$-square ini kemudian digunakan dalam perhitungan $Q$-square dengan hasil yaitu 0.96. Berdasarkan penelitian ini dapat ditarik kesimpulan bahwa model UTAUT 2 dan EUCS dapat digunakan untuk mengevaluasi sistem informasi berdasarkan tingkat penerimaan dan kepuasan pengguna yang memiliki goodness of fit yang baik sebesar $96 \%$.

\section{REFERENCES}

[1] A. S. Ahmar, Panduan Sistem Informasi Akademik Sekolah Berbasi Web, Cetakan 1., no. May. Sulawasi Selatan: Yayasan Ahmar Cendekia Indonesia, 2019.

[2] A. W. Doni, "Evaluasi SDM Sistem Informasi Akademik Poltekkes Kemenkes Padang Menggunakan Framework COBIT 5," J. Resti, vol. 1, no. 2, pp. 146-152, 2017.

[3] A. Jameel, A. Nawaiseh, Y. Helmy, and E. Khalil, "A New Software Quality Model For Academic Information Systems " Case Study E-Learning System "," vol. 9, no. 01, 2020.

[4] R. Realize, "Analysis of Trust through Academic Information System and Image of Private University," Arch. Bus. Res., vol. 6, no. 6, pp. 252-259, 2018, doi: 10.14738/abr.66.3565.

[5] C. Dewi et al., "Penerapan Model UTAUT Untuk Pemahaman Sistem Informasi Akademik di Politeknik Negeri Sriwijaya," Semin. Nas. Teknol. Inf. dan Komun. 2018 (SENTIKA 2018), pp. 23-24, 2018.

[6] D. Hadiansyah and T. Dirgahayu, "Evaluasi Sistem Informasi Akademik Universitas Mercu Buana Yogyakarta Menggunakan UTAUT2," J. Multimed. Artif. Intell., vol. 4, no. 1, pp. 1-12, 2020.

[7] S. Sutanto, I. Ghozali, and R. S. Handayani, "Faktor-Faktor Yang Memengaruhi Penerimaan Dan Penggunaan Sistem Informasi Pengelolaan Keuangan Daerah (SIPKD) Dalam Perspektif the Unified Theory of Acceptance and Use of Technology 2 (UTAUT 2) Di Kabupaten Semarang," J. Akunt. Dan Audit., vol. 15, no. 1, pp. 37-68, 2018, doi: 10.14710/jaa.15.1.37-68.

[8] A. S. Damayanti, Y. T. Musityo, and A. D. Herlambang, "Evaluasi Kepuasan Pengguna Aplikasi Tapp Market Menggunakan Metode EUCS (End User Computing Satisfaction),” J. Pengemb. Teknol. Inf. dan Ilmu Komput., vol. 2, no. 11, pp. 4833-4839, 2018

[9] E. Sorongan, H. Hilmansyah, and H. Hadiyanto, "Pengaruh Variabel Kualitas Sistem Informasi Terhadap Kepuasan Pengguna Sistem Informasi Model EUCS,” J. RESTI (Rekayasa Sist. dan Teknol. Informasi), vol. 3, no. 1, pp. 23-28, 2019, doi: 10.29207/resti.v3i1.777.

[10] E. Nur Sasongko, Mustafid, and A. Rusgiyono, "PENERAPAN METODE STRUCTURAL EQUATION MODELING UNTUK ANALISIS KEPUASAN PENGGUNA SISTEM INFORMASI AKADEMIK TERHADAP KUALITAS WEBSITE (Studi Kasus pada Website sia.undip.ac.id),” J. Gaussian, vol. 5, no. 3, pp. 395-404, 2016, [Online]. Available: http://ejournal-s1.undip.ac.id/index.php/gaussian.

[11] F. Yusup, "Uji Validitas dan Reliabilitas Instrumen Penelitian Kuantitatif," J. Tarb. J. Ilm. Kependidikan, vol. 7, no. 1, pp. 17-23, 2018, doi: 10.18592/tarbiyah.v7i1.2100.

[12] M. B. Suryawan and Prihandoko, "Evaluasi Penerapan SIAKAD Politeknik Negeri Madiun Menggunakan Pendekatan TAM dan EUCS," Citec J., vol. 4, no. 3, pp. 233-244, 2018.

[13] H. Taherdoost, "Sampling Methods in Research Methodology; How to Choose a Sampling Technique for Research," Int. J. Acad. Res. Manag., vol. 5, no. 3, pp. 18-27, 2018, doi: 10.2139/ssrn.3205035.

[14] A. Hasibuan, Metodologi Penelitian: Kualitatif dan Kuantitatif. Sumatera Utara: Universitas Islam Negeri Sumatera Utara, 2020.

[15] Sugiyono, "Metode Penelitian Kuantitatif, Kualitatif, dan R\&D.” Alfabeta, Bandung, 2017.

[16] V. H. Pranatawijaya, Widiatry, R. Priskila, and P. B. A. A. Putra, "Penerapan Skala Likert dan Skala Dikotomi Pada Kuesioner Online Pengembangan Aplikasi Kuesioner Survey Berbasis Web Menggunakan Skala Likert dan Guttman," J. Sains dan Inform., vol. 5, no. 2, pp. 128-137, 2019, doi: 10.34128/jsi.v5i2.185.

[17] R. Hamid and S. Anwar, STRUCTURAL EQUATION MODELING (SEM) BERBASIS VARIAN : Konsep Dasar dan Aplikasi dengan Program SmartPLS 3.2.8 dalam Riset Bisnis, Cetakan 1. Jakarta Pusat: PT Inkubator Penulis Indonesia, 2019.

[18] E. U. N. Sholiha and M. Salamah, "Structural Equation Modeling-Partial Least Square untuk Pemodelan derajat Kesehatan Kabupaten/Kota di Jawa Timur (Studi Kasus Data Indeks Pembangunana Kesehatan Masyarakat Jawa Timur 2013)," J. Sains Dan Seni ITS, vol. 4, no. 2, pp. 4-9, 2015 
JURNAL MEDIA INFORMATIKA BUDIDARMA

Volume 5, Nomor 3, Juli 2021, Page 1124-1132

ISSN 2614-5278 (media cetak), ISSN 2548-8368 (media online)

Available Online at https://ejurnal.stmik-budidarma.ac.id/index.php/mib

DOI 10.30865/mib.v5i3.3074

[19] V. Venkatesh, J. Y. L. Thong, and X. Xu, "Consumer acceptance and use of information technology: Extending the unified theory of acceptance and use of technology," MIS Q. Manag. Inf. Syst., vol. 36, no. 1, pp. 157-178, 2012, doi: $10.2307 / 41410412$.

[20] M. S. Gayatrie, A. Kusyanti, and M. C. Saputra, "Analisis Penerimaan Os Windows 10 Dengan Unified Theory of Acceptance and Use of Technology (UTAUT2)," Pengemb. Teknol. Inf. dan Ilmu Komput., vol. 1, no. 6, pp. 514-523, 2017, [Online]. Available: http://j-ptiik.ub.ac.id.

[21] A. Anwar, "Analisis Penerimaaan Pemustaka Terhadap Institutional Repository Berbasis E-Prints di Perpustakaan Universitas "Aisyiyah Yogyakarta Sebuah Pendekatan Integratif antara Technology Acceptance Model dan End User Computing Satisfaction,” Universitas Islam Negeri Sunan Kalijaga Yogyakarta, 2017. 